\section{Evaluation of genetic parameters and clonal selection of Eucalyptus in the Cerrado region}

\author{
Rodrigo de Sousa Oliveira ${ }^{1^{*}}$, Carlos Vinícius Gonçalves \\ Ribeiro' ${ }^{2}$, Deisiany Ferreira Neres ${ }^{1}$, Antônio Carlos da Mota \\ Porto $^{2}$, Dalton Ribeiro ${ }^{3}$, Leandro de Siqueira ${ }^{4}$, Edival Ângelo \\ Valverde Zauza ${ }^{4}$, Alexandre Siqueira Guedes Coelho ${ }^{1}$, Cristiane \\ Aparecida Fioravante Reis ${ }^{5}$, Acelino Couto Alfenas ${ }^{6}$ and \\ Evandro Novaes ${ }^{2}$
}

\begin{abstract}
Eucalyptus plantations in Brazil are expanding toward the northern and mid-western regions of the country. The objective of the present study was to select clones adapted to the local conditions, with a focus on the Cerrado region. Three clonal experiments were conducted in the municipalities of Catalão, Corumbá-de-Goiás, and Luziânia, in Goiás State, with 109 genotypes of eucalypts. The experimental design consisted of a randomized complete block design with single-tree plots and 29 blocks. Diameter at breast height and total height of all trees were measured four years after planting, for use in the estimation of wood volume for each genotype. The genotype $x$ environmental interaction was significant and predominantly (74\%) complex. The genotypic correlation among environments was moderate $(<0.47)$, indicating that clones should be selected for specific sites. However, some clones performed relatively well across all environments, such as clones CCL21, CCL30, AEC144, CCLO7, and CCL35.
\end{abstract}

Keywords: Clonal forestry, biometric models, GXE interaction, forest breeding.

\section{INTRODUCTION}

The Brazilian forestry sector is highly competitive in the international market, contributing R\$ 86.6 billion to the Brazilian GDP annually. Eucalyptus plantations account for $72.4 \%$ of the 7.83 million hectares of Brazilian commercial forests (IBÁ 2019). In Brazil, the most planted species are Eucalyptus grandis and Eucalyptus urophylla and their hybrids (Assis et al. 2015), achieving wood productivity records globally, with an average of $37 \mathrm{~m}^{3} \mathrm{ha}^{-1}$ year' (IBÁ 2019), and the potential to achieve a productivity higher than $60 \mathrm{~m}^{3} \mathrm{ha}^{-1}$ year ${ }^{-1}$ (Stape et al. 2010). Eucalypts have been used for diverse applications, such as cellulose, charcoal, sawn timber, wood panel, and biomass production (Flores et al. 2016, IBÁ 2019). The high growth rate in relatively short cycles are due to the environmental conditions in Brazil, in addition to the advanced of silvicultural techniques and advances in genetic breeding techniques (Assis et al. 2015).

In the past, Eucalyptus plantations were concentrated in the South and Southeastern regions of Brazil, mostly within the Atlantic Forest biome (Reis et al. 2017). Currently, new plantation regions are being sought, which have lower land value, higher tax incentives, and greater flexibility in terms of infrastructure
Crop Breeding and Applied Biotechnology 20(3): e29982031, 2020 Brazilian Society of Plant Breeding. Printed in Brazil http://dx.doi.org/10.1590/198470332020v20n3a35
*Corresponding author: E-mail: oliveiraflorestal.rodrigo@gmail.com (D) ORCID: : 0000-0002-0617-4293

Received: 20 November 2019 Accepted: 27 April 2020 Published: 20 July 2020

${ }^{1}$ Universidade Federal de Goiás, Departamento de Genética e Melhoramento de Plantas,

74.690-900, Goiânia, GO, Brazil

${ }^{2}$ Universidade Federal de Lavras, 37.200-000, Lavras, MG, Brazil

${ }^{3}$ CMOC International Brasil, 75.715-000, Ouvidor, GO, Brazil

${ }^{4}$ Suzano S.A., 65.907-230, Imperatriz, MA, Brazil

${ }^{5}$ Empresa Brasileira de Pesquisa Agropecuária - Embrapa Florestas, 83.411-000, Colombo, PR, Brazil

${ }^{6}$ Universidade Federal de Viçosa, 36.570-900, Viçosa, MG, Brazil 
and logistics, with the aim of increasing competitiveness in the international market. Consequently, over the years, plantations have expanded to other regions, mainly already anthropized rural areas in the Cerrado biome (Fernandes et al. 2016). Over the last ten years, the eucalyptus plantation area in such new forest frontiers has increased by $85 \%$, or 810.000 ha (Reis et al. 2017, IBÁ 2019). Consequently, it is critical to readapt silvicultural practices considering the new edaphic and climatic conditions, with particular attention to the selection and development of new Eucalyptus clones that are tolerant to drought and other stress factors in the Cerrado region.

The Cerrado climate is classified as Aw, based on the Köppen classification: it is tropical with dry winters, and an average temperature of $22{ }^{\circ} \mathrm{C}$ and an average annual rainfall of $1.500 \mathrm{~mm}$, with $85 \%$ of the rain concentrated in the rainy season from October to April (Alvares et al. 2013). The area occupied by the Cerrado biome ( $23 \%$ of Brazil) is found at altitudes ranging from $300 \mathrm{~m}$ to $1.600 \mathrm{~m}$ (Sano et al. 2020). Eucalyptus plantations in some Cerrado regions have a productivity greater than $45 \mathrm{~m}^{3} \mathrm{ha}^{-1}$ year'; however, in other regions have lower productivity, ranging from 15 to 30 $\mathrm{m}^{3}$ ha $^{-1}$ year ${ }^{-1}$ (Binkley et al. 2017), which is due, in part, to the scarcity of genotypes adapted to the climatic conditions of the Cerrado. The selection of genotypes adapted to a region is one of the most critical steps in breeding programs (Vencovsky and Barriga 1992). Thus, it is essential to know the productive capacity of the genotypes and understand the environmental effect in their selection (Oliveira et al. 2018, Pupin et al. 2018).

Goiás state is at the center of the Cerrado biome (Fernandes et al. 2016). Therefore, the selection of Eucalyptus clones adapted to the environmental conditions of Goiás could reveal genotypes with both high wood productivity and adaptation to other regions of the Cerrado biome. Therefore, the objective of the present study was to select clones with high wood productivity in three locations within Goiás and to characterize the genotypes $\times$ environmental (GXE) interaction among the regions. The results of the present study could enhance our understanding of the eucalyptus clones adapted to the Cerrado regions, where eucalyptus plantations have been expanding.

\section{MATERIAL AND METHODS}

\section{Description of experiments and calculation of mean annual increments}

The clonal plants were planted in Catalão, Corumbá-de-Goiás, and Luziânia, all of them in the state of Goias, in December 2012. The regions have conditions typical of the Cerrado biome, with a distinct dry season and dystrophic soils (Table 1). The treatments consisted of 109 clones derived from 12 pure species and their hybrids (Corymbia citriodora,

Table 1. Geographic coordinates and environmental conditions of the sites where the clonal tests of Corymbia and Eucalyptus were installed in the Goiás state

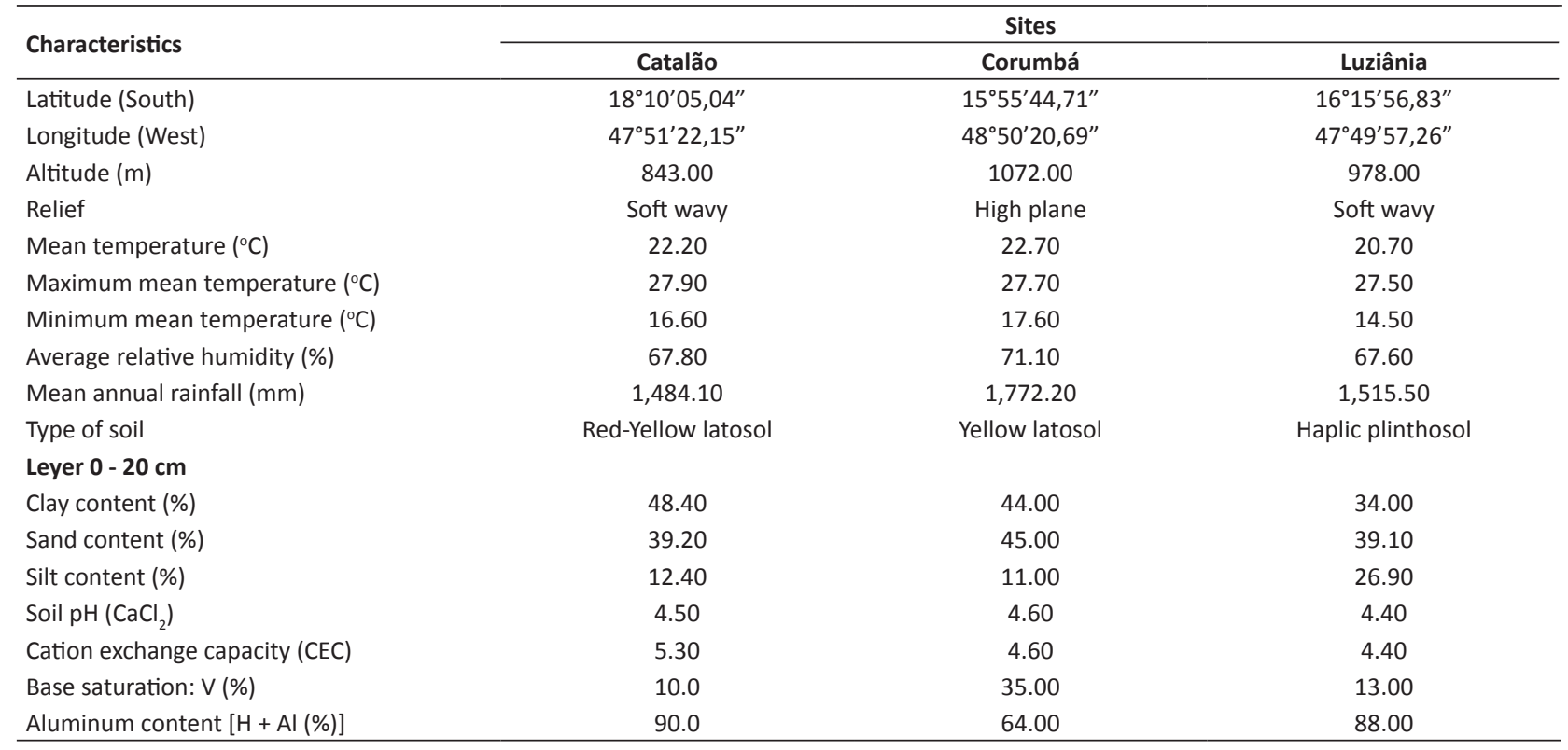


C. torelliana, Eucalyptus brassiana, E. camaldulensis, E. cloeziana, E. grandis, E. pellita, E. platyphylla, E. resinifera, E. saligna, E. tereticornis, and E. urophylla). Most clones are from E. urophylla $(\mathrm{N}=52)$ and from $E$. urophylla $\times E$. grandis $(\mathrm{N}=27)$, considering their high productivity potential in the targeted region. In total, 93 or 94 clones were evaluated at each site, with 85 common clones among all three sites. The experiments were set up in a randomized complete block design, with 29 replicates in single tree plots, using a $3.0 \times 3.0 \mathrm{~m}$ spacing between trees. AEC144 (E. urophylla) was used as the control, since it is the most cultivated clone in the region (Reis et al. 2017).

Silvicultural practices were conducted as recommended for the crop. Briefly, surface liming was performed with the incorporation of limestone at a depth of $80 \mathrm{~cm}$ within the planting line. Fertilizer was also applied within the planting lines at a rate of $300 \mathrm{~kg} \mathrm{ha}^{-1}$ (NPK 10-30-10) with $0.5 \mathrm{~kg} \mathrm{ha}^{-1}$ of boron. At 3, 12, and 24 months after planting, topdressing was applied at a rate of $180 \mathrm{~kg} \mathrm{ha}^{-1}$ (NPK 12-05-12) with $0.5 \mathrm{~kg} \mathrm{ha}^{-1}$ of boron. Invasive grasses and leaf-cutting ants controlled chemically with glyphosate and fipronil, respectively, using recommended doses.

At four years, tree height $(\mathrm{Ht})$ was measured, using a Haglöf ECll clinometer, in meters and circumference at breast height $(\mathrm{CBH})$ was measured with a measuring tape in $\mathrm{cm}$. Wood volumes in individual trees with bark $\left(V_{\text {est }}\right)$ were estimated using equation (1), in $\mathrm{m}^{3}$. The mean annual increment (MAI) was obtained by extrapolating the estimated volume for one hectare divided by age. The MAI was adopted as the productivity indicator in the statistical analyses.

$$
V_{\text {est }}=\frac{c b h^{2} * H t}{40000 * \pi} * 0.46
$$

\section{Statistical analyses}

All analyses were performed based on a mixed effects model using a free softwares Selegen-REML/BLUP (Resende 2016) and R (R Core Team 2019). In the model (2), $y$ is the data vector; $r$ is the vector of fixed effects of blocks within environments; $g$ is the vector of random genotypic effects; $g e$ is the vector of random GXE interaction effects, and $e$ is the vector of errors, which is always random. The letters $X, Z$, and $W$ represent the incidence matrices for the effects.

$$
y=X r+Z g+W g e+e
$$

Variance components were predicted using the Restricted Maximum Likelihood (REML) method. The individual broad-sense heritability $\left(h_{g}^{2}\right)$, broad-sense heritability based on the clonal averages $\left(h_{m}^{2}\right)$, the coefficient of determination of GXE interaction effects $\left(c_{g \times e}^{2}\right)$, and the genotypic correlation $\left(r_{g}\right)$ of clones through the environments, were calculated in terms of clonal means using the equations (3), (4), (5) and (6), where $\sigma_{g}^{2}$ is the genotypic variance; $\sigma_{g x e}^{2}$ is the GxE interaction variance, $\sigma_{e}^{2}$ is the residual variance, $b$ is the number of sites $(b=3)$, and $r$ is the number of replicates (blocks) within each site $(r=29)$. Coefficients of variation, i.e., the ratio between the specific standard deviation by the general mean, were estimated for the genotypic $\left(C V_{g}\right)$ and environmental $\left(C V_{e}\right)$ variances.

$$
h_{g}^{2}=\frac{\sigma_{g}^{2}}{\sigma_{g}^{2}+\sigma_{g \times e}^{2}+\sigma_{e}^{2}}(3)
$$

$$
h_{m}^{2}=\frac{\sigma_{g}^{2}}{\sigma_{g}^{2}+\frac{\sigma_{g \times e}^{2}}{b}+\frac{\sigma_{e}^{2}}{r}} \text { (4) }
$$

$$
c_{g \times e}^{2}=\frac{\sigma_{g \times e}^{2}}{\sigma_{g}^{2}+\sigma_{g \times e}^{2}+\sigma_{e}^{2}}(5)
$$

$$
r_{g}=\frac{h_{g}^{2}}{h_{g}^{2}+c_{g \times e}^{2}}(6)
$$

An analysis of deviance was used to evaluate the significance of random effects using a likelihood ratio test (Resende 2007). When significant, G×E interaction was decomposed in two parts: simple and complex. The decomposition was performed according to Cruz and Castoldi (1991), with adaptations for three sites (Ramalho et al. 2012). It estimates the variance for all sites $\left(V_{L S}\right)$ based on GXE interaction coefficient $\left(r_{G \times E}\right)$ and the variance of the different sites $\left(V_{L n}\right.$ or $\left.V_{L n^{\prime}}\right)$.

$$
V_{L S}=\frac{1}{n(n-1)} \sum_{n<n^{\prime}}\left(\sqrt{V_{L n}}-\sqrt{V_{L n^{\prime}}}\right)^{2}+2\left(1-r_{G X E}\right) \cdot \sqrt{V_{L n} V_{L n^{\prime}}}
$$

The genotypic value of productivity (MAI) for each clone was estimated using the Best Linear Unbiased Prediction (BLUP) model. Stability and adaptability of each clone was evaluated according to Resende (2007). MAI stability was estimated for each genotype using the harmonic means of genotypic value (HMGV), and the harmonic mean increases with a decrease in standard deviation (Resende 2007). Adaptability was estimated based on the average relative performance of the genotypic value over the local average (RPGV). Finally, genotypes were selected based on an index estimated using the harmonic mean of the relative performance of the predicted genotypic values (HM-RPGV), which take into account productivity, stability, and adaptability (Resende 2007). 


\section{RESULTS AND DISCUSSION}

\section{Genetic Parameters for MAI}

E. urophylla exhibits good adaptation in sites with predominantly tropical climates (Assis et al. 2015, Flores et al. 2016). The average survival of the trees in the three sites was $95.8 \%$, ranging from $94.5 \%$ in Corumbá-de-Goiás, $95.5 \%$ in Catalão, to $97.1 \%$ in Luziânia. Such survival rates are considered high, and they indicated that the experiments were properly conducted and there was a good adaptation of the clones, as observed in other clonal tests with Eucalyptus sp. (Silva et al. 2017, Amâncio et al. 2020).

The Pearson's correlations for $\mathrm{Ht} \times \mathrm{MAl}$ and $\mathrm{DBH} \times \mathrm{MAl}$ were 0.85 and 0.87 , respectively. There was also a high correlation between $\mathrm{Ht}$ and $\mathrm{DBH}$, which ranged from 0.85 to 0.95 . Correlations between $\mathrm{DBH}$ and $\mathrm{Ht}$ ranging from 0.73 to 0.98 were observed in other clonal tests of Eucalyptus sp. (Tambarussi et al. 2017). The high correlation for $\mathrm{Ht} \times \mathrm{DBH}$ was probably due to pleiotropy in the genetic control of traits. Therefore, all genes that control the growth and development of trees, such as those that influence nutrient absorption, photosynthesis, and respiration, would influence the height and DBH of trees (Pupin et al. 2017). Considering the high correlations among all the traits evaluated, the MAI was used to evaluate the productivity of the clones and to estimate the genetic parameters.

Relatively high productivity averages were observed for the three sites, ranging from 38.7 to $50.7 \mathrm{~m}^{3} \mathrm{ha}^{-1}$ year $^{-1}$ (Table 2). The values correspond to the average MAl observed in other regions of the Cerrado and are above the national average of $\mathrm{m}^{3} \mathrm{ha}^{-1}$ year $^{-1}$ (Reis et al. 2017). Sites with high productivity are considered suitable for eucalyptus plantations (Nunes et al. 2016, Tambarussi et al. 2017). The genotypic values for MAI were predicted with high accuracy, according Resende and Duarte (2007), ranging from 0.81 (Joint) to 0.98 (Catalão and Luziânia) (Table 2).

High accuracy estimates, indicated by high relative coefficients of variation $\left(C V_{r}\right)$, which ranged between 0.54 (Joint) to 1.05 (Catalão), indicated high experimental quality and reliability of the estimates. High accuracy is vital for selection purposes, and for the accurate estimation of genotypic values (Resende 2007). The $C V_{r}$ can be lower than unit when the number of repetitions is high and still facilitate high levels of precision (Resende and Duarte 2007). According these authors, the results demonstrate that the experimental design and the number of replicates ( 29 blocks) were adequate, which would ensure reliability in the predictions of genotypic values and genetic parameters.

Table 2. Estimates of genetic parameters (using REML), average and correlation for wood productivity traits at 4 years of age ( $\mathrm{m}^{3}$ ha $^{-1}$ year $^{-1}$ ) evaluated in three clonal tests with 109 genotypes of the Corymbia and Eucalyptus genera. Tests were planted in the municipalities of Catalão, Corumbá-de-Goiás and Luziânia of Goiás state. The analyzes were performed for each site and for all three environments in a joint analysis

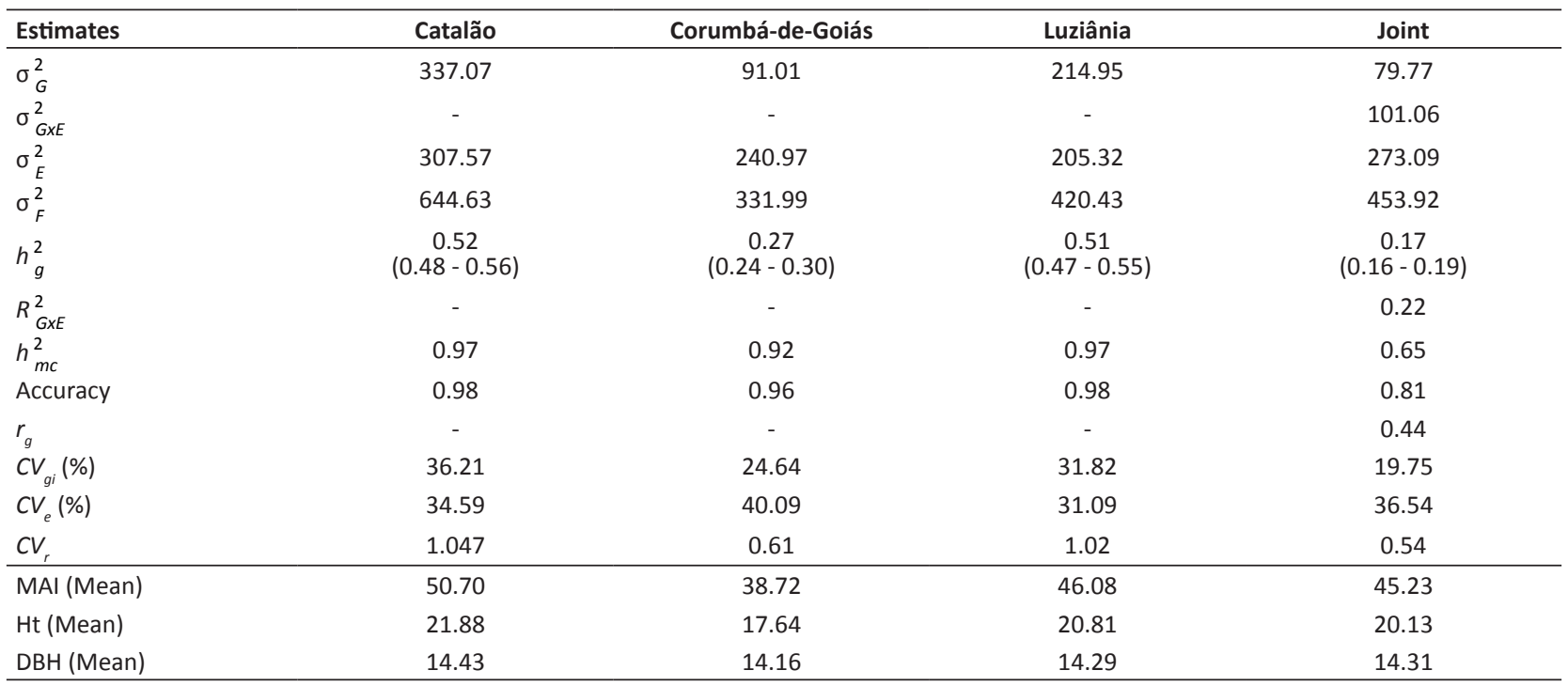

$\sigma_{G}^{2}$ : Genetic variance; $\sigma_{G \times E}^{2}:$ Variance of the interaction of GxE; $\sigma_{E}^{2}:$ Environmental variance; $\sigma_{F}^{2}:$ Phenotypic variance; $h_{g}^{2}$ : heritability; $R_{G \times E}^{2}:$ coefficient of determination of the interaction $\mathrm{GxE} ; h_{m c}^{2}$ : mean heritability per clone; $r_{g}$ : genotype correlation of clones performance between environments; $C V_{g i}$ (\%): Genotype $V^{g}$ ariation Coefficient; $C V_{e}$ (\%): Coefficient of environmental variation; $\mathrm{CV}_{r}$ : Relative Variation Coefficient. 


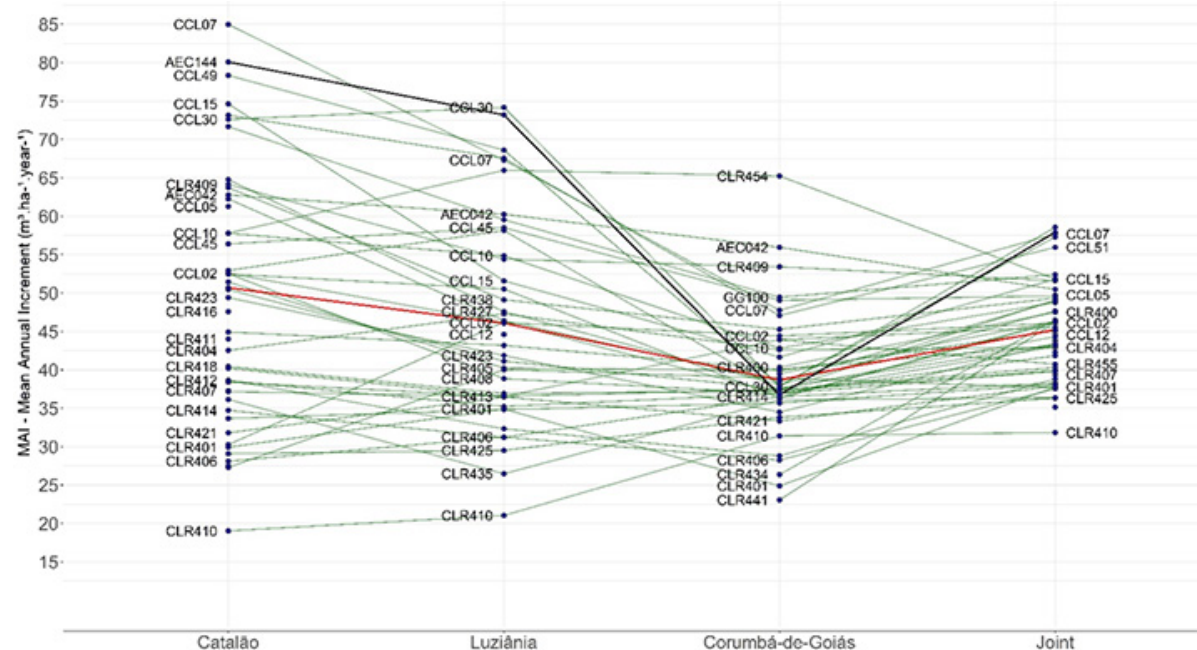

Figure 1. BLUP estimates for wood productivity at 4 years of age $\left(\mathrm{m}^{3}\right.$.ha $\mathrm{h}^{-1}$.year $\left.\mathrm{r}^{-1}\right)$ evaluated in three clonal tests with a total of 109 clones of the Corymbia and Eucalyptus genera in Goiás, in the municipalities of Catalão, Corumbá-de-Goiás and Luziânia. The analyzes were performed for each site and for all three environments in a joint analysis. Red line indicates the site average and black line indicate the productivity of the control clone (AEC144).

The $C V_{r}$ represents the ratio of the existing coefficient of genetic variation $\left(C V_{g}\right)$ to the coefficient of environmental variation $\left(C V_{e}\right)$. The $C V_{g}$ values were moderate (Table 2), allowing precise selection of superior genotypes (Resende and Duarte 2007). Similar accuracy values, $C V_{r}$ and $C V_{g}(\%)$, were obtained in clonal tests of Eucalyptus sp. with 30 repetitions (Santos et al. 2015, Nunes et al. 2016). The broad-sense heritability $\left(h_{g}^{2}\right)$ for MAl ranged from 0.27 (Corumbá-de-Goiás) to 0.52 (Catalão and Luziânia), being lower for the Joint analyses of all sites (0.17), indicating the existence of a GXE interaction.

All $h_{g}^{2}$ were significantly different from zero (Table 2). The $h_{g}^{2}$ values are considered moderate to high, indicating the existence of genetic variability and the possibility of selection (Resende and Duarte 2007). The genotypic effects of the clones and the effects of blocks were significant at 1\% probability, indicating genetic differences among the tested clones and that the experimental design could effectively control for the environmental heterogeneity, respectively. The GXE interaction $\left(\sigma_{G \times E}^{2}\right)$ was higher than the genetic variance (Table 2 ), demonstrating that the environmental differences between sites significantly influenced the relative performance of the clones, which was very evident based on the changes in the rankings of the clones across the different sites (Figure 1).

The highest $C V_{e}$ was observed in Corumbá-de-Goiás, indicating that the environment was the most heterogeneous (Table 2). This can also be demonstrated by the moderate MAI heritability values $\left(h_{g}^{2}\right)$ in Corumbá-de-Goiás $(0.27)$ relative to in the other two sites. The greater $\mathrm{CV}_{e}$ in Corumbá-de-Goiás was probably caused by apex die-back due to water deficit and apparent boron insufficiency, in several trees, during of the first year (data not shown). In addition, the drought stress in Corumbá-de-Goiás could have facilitated the selection of dry tolerant genotypes.

The broad-sense-heritability based on the clonal averages $\left(h_{m}^{2}\right)$ was high, ranging from 0.65 for the joint analyses of all three environments to 0.92 for Corumbá-de-Goiás and 0.97 for Catalão and Luziânia. An adequate number of clone repetitions increases the $h_{m}^{2}$ and decreases the influence of the environmental variation and experimental errors, further increasing the selection accuracy (Vencovsky and Barriga 1992). Moreover, greater accuracy in genotype classification increases the selection gains. Average heritabilities $\left(h_{m}^{2}\right)$ between 0.22 to 0.64 were observed for dendrometric traits in various Eucalyptus sp. clones (Nunes et al. 2016, Santos et al. 2015, Resende et al. 2017, Tambarussi et al. 2017, Furlan et al. 2020).

\section{GxE Interaction}

The determination coefficient of the G×E interaction $\left(R_{G \times E}^{2}\right)$ was 0.22 and significant at $1 \%$. The differential responses of the clones to the environmental variation (Figure 1) demonstrate the occurrence of interaction. The interaction can 
Table 3. Genotypic values (BLUP) for wood productivity at 4 years of age $\left(\mathrm{m}^{3} \mathrm{ha}^{-1}\right.$ year $\left.{ }^{-1}\right)$ of the best and worst clones evaluated in three clonal tests with 109 genotypes of the Corymbia and Eucalyptus genera. Tests were planted in the municipalities of Catalão, Corumbá-de-Goiás and Luziânia of Goiás state. The predicted selection gains, with respect to the local population mean, is also depicted for each clone

\begin{tabular}{|c|c|c|c|c|c|c|c|c|c|c|c|c|c|c|c|}
\hline \multicolumn{4}{|c|}{ Catalão } & \multicolumn{4}{|c|}{ Corumbá-de-Goiás } & \multicolumn{4}{|c|}{ Luziânia } & \multicolumn{4}{|c|}{ Joint } \\
\hline $\mathbf{R}$ & Clone & $u+g$ & G (\%) & $\mathbf{R}$ & Clone & $u+g$ & G (\%) & $\mathbf{R}$ & Clone & $\mathrm{u}+\mathrm{g}$ & G (\%) & $\mathbf{R}$ & Clone & $\mathrm{u}+\mathrm{g}$ & G (\%) \\
\hline 1 & CCL21 & 88.52 & 74.59 & 1 & CLR454 & 65.24 & 68.52 & 1 & CCL21 & 77.62 & 68.45 & 1 & CCL21 & 60.47 & 33.68 \\
\hline 2 & CCLO7 & 84.99 & 67.61 & 2 & CCL35 & 60.15 & 55.35 & 2 & CCL30 & 74.18 & 60.97 & 2 & CCL30 & 58.56 & 29.47 \\
\hline 3 & CCL36 & 83.27 & 64.23 & 3 & CCL60 & 57.09 & 47.44 & 3 & AEC 144 & 73.2 & 58.86 & 3 & AEC 144 & 57.92 & 28.05 \\
\hline 4 & CCL35 & 81.36 & 60.46 & 4 & AEC 042 & 55.95 & 44.52 & 4 & CCL59 & 70.57 & 53.14 & 4 & CCLO7 & 57.69 & 27.54 \\
\hline 5 & $\mathrm{CCL} 27$ & 80.36 & 58.49 & 5 & CCL21 & 55.06 & 42.22 & 5 & CCL50 & 68.61 & 48.89 & 5 & CCL35 & 57.46 & 27.03 \\
\hline$\ldots$ & $\ldots$ & $\ldots$ & $\ldots$ & $\ldots$ & $\ldots$ & $\ldots$ & $\ldots$ & $\cdots$ & $\ldots$ & $\ldots$ & $\ldots$ & $\ldots$ & $\ldots$ & $\ldots$ & $\ldots$ \\
\hline 92 & Toreliodora & 14.70 & -71.00 & 91 & CLR441 & 23.06 & -40.5 & 91 & CCL57 & 19.8 & -57.04 & 107 & CCL54 & 30.91 & -31.7 \\
\hline 93 & CCL54 & 14.57 & -71.30 & 92 & Toleriodora & 20.66 & -46.7 & 92 & C. citriodora & 12.48 & -72.91 & 108 & Toreliodora & 28.64 & -36.7 \\
\hline 94 & C. citriodora & 13.65 & -73.10 & 93 & C. citriodora & 16.42 & -57.6 & 93 & Toreliodora & 11.85 & -74.28 & 109 & C. citriodora & 28.38 & -37.3 \\
\hline
\end{tabular}

ranking; $\mathrm{u}+\mathrm{g}$ : Genotypic value; g: genetic gain in relation to the average; $\mathrm{G}(\%)$ : genetic gain in percentage relative to the average.

be decomposed into a simple term, which is the difference in variability among genotypes in the sites and was in part due to the low genetic correlation among the sites (Cruz and Castoldi 1991, Ramalho et al. 2012). In the decomposition of the GXE interaction, $26.04 \%$ and $73.96 \%$ of the variance was classified as simple and complex, respectively.

The low genetic correlation among the environments $\left(r_{g}=0.44\right)$ and the different rankings among clones in the sites (Figure 1) demonstrates the complex interaction. The genetic correlations between pairs of sites were classified as low according to Resende and Duarte (2007), being 0.42 for Catalão-Corumbá, 0.46 for Catalão-Luziânia, and 0.37 for Corumbá-Luziânia. The low correlations highlight the need to select and recommend different genotypes based on sites (Cruz and Castoldi 1991). This high GxE interaction is surprising considering the sites are not very far apart (greatest distance is 200 km, between Corumbá-de-Goiás and Catalão) and all experiments were carried out in Cerrado regions.

There are numerous strategies of minimizing GxE interaction effects, for example, by identifying genotypes exhibiting specific adaptation to specific environments (Cruz and Castoldi 1991) or the stratification of a heterogeneous area into more homogeneous parts, referred to as breeding zones, where the genotype selection is performed separately in each zone (Vencovsky and Barriga 1992, Santos et al. 2015). Based on the significant and complex interactions observed in the present study, the selection of clones for plantations in regions such as the ones evaluated would be challenging. Therefore, we recommend that producers test several clones before selected the genotypes to be planted.

\section{Genetic gains}

The genetic gain predicted with selection of the best clone at each site was $58 \%$ in Catalão, $47.2 \%$ in Luziânia, 38\% in Corumbá-de-Goiás, and $26.7 \%$ in the combined analyses with three sites (Table 4). The control clone (AEC144) was among the best clones at all the sites, except in Corumbá-de-Goiás. Therefore, the genetic gains of the best clones were 6, 10.5, and 49.4\%, higher than in the control (AEC144) in Catalão, Luziânia, and Corumbá-de Goiás, respectively. In the combined analysis, the best clone was CCL21 (E. urophylla $\times$ E. grandis), which was $4.4 \%$ more productive than clone AEC144 (Table 4).

In Catalão, the best clones were CCL21, CCL07 (E. urophylla), CCL36 (E. urophylla $\times$ E. grandis), CCL35 (E. urophylla $\times$ E. grandis), CCL27 (E. grandis $\times$ E. urophylla), and AEC144. The best clone in Luziânia was also CCL21, followed by $\operatorname{CCL30~(E.~urophylla),~AEC144,~CCL59~(E.~urophylla~} \times$ E. grandis), CCL50 (E. urophylla $\times$ E. grandis) and CCL27. The average productivity observed in Corumbá-de-Goiás was the lowest, with $38.7 \mathrm{~m}^{3} \mathrm{ha}^{-1}$ year ${ }^{-1}$. At the site, clones CLR454 (E. urophylla), CCL35, CCL60 (E. camaldulensis), AEC042 (E. urophylla), CCL21, and CLR409 (E. urophylla) were the most productive. In Corumbá-de-Goiás, the AEC144 clone exhibited below average productivity. The clones with optimal productivity in all the three sites are listed in Table 4. 
Evaluation of genetic parameters and clonal selection of Eucalyptus in the Cerrado region

Table 4. Ranking of stability (HMGV) and adaptability of the genotypic values (RPGV), as well as the index (HM-RPGV) used to take both into account for the simultaneous selection of highly productive, stable and adaptable clones at four years of age $\left(\mathrm{m}^{3}\right.$.ha-1. ${ }^{-1}$ ear $\left.{ }^{1}\right)$. Only the ten best and two worst clones are depicted for each parameter

\begin{tabular}{|c|c|c|c|c|c|c|c|c|}
\hline \multirow{2}{*}{$\begin{array}{l}\text { Ranking } \\
\text { (Position) }\end{array}$} & \multicolumn{2}{|c|}{ Stability* } & \multicolumn{3}{|c|}{ Adaptability* } & \multicolumn{3}{|c|}{ Stability and Adaptability Index* } \\
\hline & Genotype & HMGV & Genotype & RPGV & RPGV*MG & Genotype & HM-RPGV & HMRPGV*MG \\
\hline 1 & CCLO4 & 74.0610 & CCLO4 & 1.4568 & 65.8928 & CCLO4 & 1.4568 & 65.8928 \\
\hline 2 & CCL17 & 62.1938 & CCL21 & 1.4412 & 65.1859 & CCL30 & 1.3869 & 62.7303 \\
\hline 3 & CCL30 & 61.2856 & CCL30 & 1.4069 & 63.6374 & CCL21 & 1.3286 & 60.0931 \\
\hline 4 & CCLO5 & 61.0768 & AEC 144 & 1.3703 & 61.9799 & CCL35 & 1.3251 & 59.9381 \\
\hline 5 & CCL35 & 58.0690 & CCL35 & 1.3610 & 61.5603 & CCL50 & 1.3195 & 59.6845 \\
\hline 8 & CCL51 & 56.8495 & $\mathrm{CCL} 27$ & 1.3378 & 60.5126 & CCLO7 & 1.2918 & 58.4284 \\
\hline 9 & AEC 144 & 56.6272 & CCL51 & 1.3197 & 59.6924 & CCL27 & 1.2816 & 57.9704 \\
\hline 10 & CCLO7 & 56.1768 & CCL47 & 1.3087 & 59.1936 & CCL47 & 1.2582 & 56.9093 \\
\hline$\ldots$ & $\ldots$ & $\ldots$ & $\ldots$ & $\ldots$ & $\ldots$ & $\ldots$ & $\ldots$ & $\ldots$ \\
\hline 108 & Toreliodora & 17.3550 & Toreliodora & 0.5101 & 23.0745 & Toreliodora & 0.3713 & 16.7923 \\
\hline
\end{tabular}

* The stability was estimated for each genotype with the harmonic means of genotypic value (HMGV). Adaptability was estimated based on the average of the relative performance of the genotypic value over the local (or site) average (RPGV). The index was estimated based on the harmonic mean of the relative performance of the predicted genotypic values (HM-RPGV), which takes into account all parameters: productivity (MAI), stability and adaptability, as described by Resende (2007).

Although the results indicate high levels of adaptation of the clones, the number of environments analyzed in the present study was low. However, some clones exhibited low adaptation, includes Corymbia sp. clones, with the poorest growth rates observed in $C$. citriodora and Toleriodora $(C$. torelliana $\times$ C. citriodora) clones with productivity ranging between 11.85 and $20.67 \mathrm{~m}^{3} \mathrm{ha}^{-1}$ year ${ }^{-1}$. C. citriodora yield can vary between 9 and $51 \mathrm{~m}^{3} \mathrm{ha}^{-1}$ year ${ }^{-1}$ depending on the origin (Reis et al. 2013). Conversely, selected C. torelliana $\times$ C. citriodora hybrids could produce $40 \mathrm{~m}^{3} \mathrm{ha}^{-1}$ year ${ }^{-1}$ in the regions where they were selected (Reis et al. 2013).

C. citriodora and C. torelliana can be recommended for the Cerrado biome because they are tolerant to prolonged drought periods and high temperatures (Reis et al. 2013, Assis et al. 2015). However, the few clones of the species tested in our experiments had low productivity, potentially because the clones were not specifically selected in the Cerrado, and there may not be any elite clones. According to Reis et al. (2013), Corymbia sp. exhibits slow rates of development initially; therefore, they do not develop well when competing for resources with clones from Eucalyptus sp.

The use of AEC144, which is the most planted clone in Goiás (Reis et al. 2017), as a control, facilitated the validation of the results of the present study, demonstrating that there were more productive genotypes (CCL21 and CCL30) and other genotypes as productive as AEC144 (CCL07, CCL27, CCL35, CCL36, CCL50, CCL51, and CCL59). Notably, all the high productivity clones had $E$. urophylla in their genetic composition, including pure $E$. urophylla or hybrids with $E$. grandis.

Most of the national plantations constitute E. urophylla clones, due to the high adaptive capacity and high productive stability in almost all regions of Brazil (Flores et al. 2016, Assis et al. 2015). In addition, the high productivity of $E$. grandis makes $E$. urophylla $\times E$. grandis prominent in Brazilian clonal forestry (Assis et al. 2015). However, considering the genetic diversity within the species, some $E$. urophylla genotypes do not exhibit good productivity, as observed in some clones evaluated in the present study.

In Corumbá-de-Goiás, a E. camaldulensis clone (CCL60) was among the most productive. The occurrence of higher water deficits at the site should have promoted superior E. camaldulensis development, as it is recommended for more arid regions (Assis et al. 2015). However, generally, E. camaldulensis is very susceptible to infestation by various insect pests, such as Red gum lerp psyllid (Glycaspis brimblecombei), blue gum chalcid wasp (Leptocybe invasa), and bronze bug (Thaumascotocoris peregrinus) (Rinaldi et al. 2013, Camargo et al. 2014). Therefore, the recommendation of the planting of E. camaldulensis clones in the Cerrado biome region should be examined carefully.

Even though there were significant and complex G×E interactions, some clones exhibited high performance in all the three tested sites (CCL21, CCL30, AEC144, CCL07, CCL35, CCL50), with levels of productivity $26.7 \%$ higher than the general 
average. Such clones should be considered in new plantations, and for use in the improvement of the genetic diversity of clones with good performance in the regions of Cerrado. The availability of a diversity of clones is essential to reduce the risks associated with biotic and abiotic stress factors in clonal forestry. The high-performing clones identified in the present study experiment could be planted in mosaic, or even as clonal mixtures, to minimize such risks even further.

\section{Stability and Adaptability}

Table 4 presents the stability (HMGV), adaptability (RPGV), and both stability and adaptability (HM-RPGV) MAI results. According to the findings, the clones identified as the most productive was not entirely consistent with the ranking of the best clones based on the predicted genotypic values (BLUPs) in the combined analysis (Table 3). The consistency was $70 \%$ among the 10 best clones, and the ranking was partly inverted among some of the clones. The inconsistency in the ranking of the best clones in the HM-RPGV and the BLUPs demonstrated that the use of stability and adaptability indices could refine selection activities (Resende 2007).

Compared to the gains observed based on the HM-RPGV in relation to the control (AEC144), the average superiority of the best genotype was $11.96 \%$. According to Resende (2007), under simultaneous selection (stability + adaptability), the gain with the average interaction between environments is emphasized. The best genotypes based on the HM-RPGV (CCL04, CCL30, CCL21, CC35, CCL50) were, on average, had productivity levels $36.35 \%$ higher than the average of the three sites $\left(45.23 \mathrm{~m}^{3} \mathrm{ha}^{-1}\right.$ year $\left.^{-1}\right)$. HM-RPGV values are obtained using harmonic means, which is a disadvantage for genotypes with unstable productivity across sites and, simultaneously, emphasizes on the capacity to respond (adaptability) to improvements in the sites conditions (Resende 2007).

One of the objectives of forest breeding activities is improving the genetic material in current plantations (Santos et al. 2015). In the present study, clones more productive than the control clone (AEC144), observed, which could be exploited to increase the diversity of clones adapted to Cerrado. Such an activity is critical for the sustainability of the eucalyptus cropping systems in such sites, particularly in the wake of climate change in the tropics (Rubilar et al. 2020). Selection based on HM-RPGV could provide greater gains by facilitating the recommendation of clones for diverse areas. Therefore, the present study presents an interesting method for recommending clones for cultivation in the Cerrado region. The recommendation of genotypes with broad adaptability and stability is essential for regions with distinct environmental conditions.

Considering recent advances of the eucalyptus plantations into the middle-western and northern regions of Brazil, there is a need to identify clones adapted to such regions. The results of the present study identifie clones with similar or higher productivity in comparison to the clone that is most planted in the region (AEC144). However, the complex GXE interaction observed complicates the recommendation of clones in the region. Therefore, more studies, over a broader area, are required to enhance the selection of clones for planting in the Cerrado region. The wood properties of some of the clones selected in the present study are being evaluated, which would facilitate specific recommendations based on end use (energy, solid wood, cellulose, etc.) for each clone in the future.

\section{ACKNOWLEDGEMENT}

To the Fundação de Amparo à Pesquisa do Estado de Goiás, FAPEG, and Suzano, for financial support. To the Coordenação de Aperfeiçoamento de Pessoal de Nível Superior (CAPES), for the fellowship for RSO. To the companies CLONAR, CMOC, and JP Florestal, and to Mr. Paulo de Morais, for supplying the clones, planting area, and for managing the experiments. To the National Council for Scientific and Technological Development-CNPq, for a productivity grant to EN.

\section{REFERENCES}

Alvares CA, Stape JL, Sentelhas PC, Gonçalves JLM and Sparovek G (2013) Köppen's climate classification map for Brazil. Meteorologische Zeitschrift 22: 711-728.

Amâncio MR, Pereira FB, Paludeto JGZ, Vergani AR, Bison O, Peres FSB and Tambarussi EV (2020) Genetic control of coppice regrowth in Eucalyptus spp. Silvae Genetica 69: 6-12.
Assis TF, Abad JIM and Aguiar AM (2015) Melhoramento genético do eucalipto. In Schumacher MV and Vieira M (eds) Silvicultura do eucalipto no Brasil. UFSM, Santa Maria, p. 225-247.

Binkley D, Campoe OC, Alvares C, Carneiro RL, Cegatta I and Stape JL (2017) The interactions of climate, spacing and genetics on clonal Eucalyptus plantations across Brazil and Uruguay. Forest Ecology and Management 405: 271-283. 
Evaluation of genetic parameters and clonal selection of Eucalyptus in the Cerrado region

Camargo JMM, Zanol KMR, Queiroz DL, Dedececk RA, Oliveira EB and Melido RCN (2014) Resistência de clones Eucalyptus ao psilídeo-deconcha. Pesquisa Florestal Brasileira 34: 91-97.

Cruz CD and Castoldi FL (1991) Decomposição da interação genótipos x ambientes em partes simples e complexa. Revista Ceres 38: 422-430.

Fernandes GW, Coelho MS, Machado RB, Ferreira ME, Aguiar LMS, Dirzo R, Scariot A and Lopes CR (2016) Afforestation of savannas: an impending ecological disaster. Natureza \& Conservação 14: 146-151.

Flores TB, Alvares CA, Souza VC and Stape JL (2016) Eucalyptus no Brasil: zoneamento climático e guia para identificação. Instituto de Pesquisas e Estudos Florestais, Piracicaba, 448p.

Furlan RA, Moraes CB and Tambarussi EV (2020) Genetic parameters of Eucalyptus spp. clones in Northeastern Brazil. Floresta 50: 1267-1278.

IBÁ - Indústria Brasileira de Árvores (2019) Relatório anual 2019: base 2018. IBÁ, Brasília, 80p.

Nunes ACP, Santos GA, Resende MDV, Silva LD, Higa A and Assis TF (2016) Estabelecimento de zonas de melhoramento para clones de eucalipto no Rio Grande do Sul. Scientia Forestalis 44: 536-574.

Oliveira TWG, Paula RC, Moraes MLT, Alvares CA, Miranda AC and Silva PHM (2018) Stability and adaptability for wood volume in the selection of Eucalyptus saligna in three environments. Pesquisa Agropecuária Brasileira 53: 611-619.

Pupin S, Silva PHM, Piotto FA, Miranda AC, Zaruma DUG, Sebbenn AM and Moraes MLT (2018) Genotype x Environment interaction, stability, and adaptability in progenies of Eucalyptus urophylla ST Blake using the AMMI model. Silvae Genetica 67: 51-56.

Pupin S, Zaruma DUG, Souza CS, Cambuim J, Coleto AL, Alves PF, Pavan BE and Moraes MLT (2017) Genetic parameters for growth traits, bark thickness and basic density of wood in progenies of Eucalyptus urophylla S.T. Blake. Scientia Forestalis 45: 455-465.

R Core Team (2019) R: A language and environment for statistical computing. Available at: <https://www.R-project.org/>. Accessed on May 7, 2019.

Ramalho MAP, Abreu AFB, Santos JB and Nunes JAR (2012) Aplicações da genética quantitativa no melhoramento de plantas autógamas. Universidade Federal de Lavras, Lavras, 522p.

Reis CAF, Assis TF, Santos AM and Paludzyszyn Filho E (2013) Corymbia citriodora: estado da arte de pesquisas no Brasil. Embrapa Florestas, Colombo, 59p.

Reis CAF, Talone Neto A, Brunckhorst A, Moreira JMMAP, Pereira AV and Moraes AC (2017) Cenário do setor de florestas plantadas no estado de Goiás. Embrapa Florestas, Colombo, 80p.
Resende MDV (2007) Matemática e estatística na análise de experimentos e no melhoramento genético. Embrapa Florestas, Colombo, 561p.

Resende MDV (2016) Software Selegen-REML/BLUP: a useful tool for plant breeding. Crop Breeding and Applied Biotechnology 16: 330-339.

Resende MDV and Duarte JB (2007) Precisão e controle de qualidade em experimentos de avaliação de cultivares. Pesquisa Agropecuária Tropical 37: 182-194.

Resende RT, Resende MDV, Silva FF and Takahashi EK (2017) Acurácia preditiva de testes clonais de Eucalyptus sp. utilizando efeitos aditivos do parentesco e validação cruzada. Scientia Forestalis 45: 39-47.

Rinaldi DAMF, Barbosa LR, Wilcken CF, Zaché B, Araújo MM and Carvalho RCZ (2013) Ocorrência de Leptocybe invasa (Hymenoptera: Eulophidae) em mudas de eucalipto no estado do Paraná. Pesquisa Florestal Brasileira 33: 327-330.

Rubilar R, Hubbard R, Emhart V, Mardones O, Quiroga JJ, Medina A, Valenzela H, Espinoza J, Burgos $Y$ and Bozo D (2020) Climate and water availability impacts on early growth and growth efficiency of Eucalyptus genotypes: The importance of GxE interactions. Forest Ecology and Management 458: 117763.

Sano EE, Bettiol GM, Martins ES, Couto Júnior AF, Vasconcelos V, Bolfe EL and Victoria DC (2020) Características gerais da paisagem do Cerrado. In Bolfe EL, Sano EE and Campos SK (eds) Dinâmica agrícola no cerrado: análises e projeções. Embrapa Cerrados, Brasília, p. 21-37.

Santos GA, Resende MDV, Silva LD, Higa A and Assis TF (2015) Interação genótipos $\mathrm{x}$ ambientes para produtividade de clones de Eucalyptus no Rio Grande do Sul. Revista Árvore 39: 81-91.

Silva PHM, Lee DJ, Miranda AC, Marino CL, Moraes MLT and Paula RC (2017) Sobrevivência e crescimento inicial de espécies de eucalipto em diferentes condições climáticas. Scientia Forestalis 45: 563-571.

Stape JL, Binkley D, Ryan MG, Fonseca S, Loos RA, Takahashi EN, Silva CR, Silva SR, Hakamada RE, Ferreira JMA, Lima AMN, Gava JL, Leite FP, Andrade HB, Alves JM, Silva GGC and Azevedo MR (2010) The Brazil Eucalyptus potential productivity project: Influence of water, nutrients and stand uniformity on wood production. Forest Ecology and Management 259: 1684-1694.

Tambarussi EV, Lima BM, Queiroz RC, Peres FSB, Dias DC, Pagliarini MK, Pereira FB, Rosa JRBF and Resende GDSP (2017) Estimativas de parâmetros genéticos para a seleção precoce em clones de Eucalyptus spp. Scientia Forestalis 45: 507-517.

Vencovsky $R$ and Barriga $P$ (1992) Genética biométrica no fitomelhoramento. Revista Brasileira de Genética, Ribeirão Preto, 496p.

(cc) EY This is an Open Access article distributed under the terms of the Creative Commons Attribution License, which permits unrestricted use, distribution, and reproduction in any medium, provided the original work is properly cited. 